\title{
De oudere werknemer na de kredietcrisis
}

\author{
Peter Smulders*
}

In september 2008 heeft de kredietcrisis hard toegeslagen. Sindsdien zijn er banken omgevallen, gefuseerd en genationaliseerd. Ook de 'gewone economie' is er stevig door geraakt. Sommige bedrijven hebben al personeel moeten ontslaan, andere hebben werknemers met verlof gestuurd en de deuren tijdelijk gesloten.

Uitzendbureaus kunnen hun flexwerkers niet meer kwijt. Honderden bedrijven hebben bij het ministerie van Sociale Zaken en Werkgelegenheid werktijdverkorting aangevraagd en gekregen.

Er is een eind gekomen aan een langdurige periode van dalende werkloosheid. Het Centraal Planbureau is niet optimistisch en verwacht een toename van de werkloosheid tot 600.000 in 2010 tegenover de 300.000 van de laatste maanden van 2008.

In januari 2009 meldde minister Donner te vrezen voor massaontslagen. En de Europese Commissie verwacht dat de Nederlandse economie in 2009 met 2\% zal krimpen. Het 'polderoverleg' tussen overheid, werkgevers en vakbonden draait op volle toeren om de schade beperkt te houden.

Zo ziet het slagveld er begin 2009 uit. Wat heeft dit alles voor effect op de positie van de oudere werknemer? Is het doorwerken van oudere werknemers dus niet meer nodig? Jawel, zeggen vele arbeidsmarktdeskundigen, en met hen de commissie-Bakker (maar die bracht zijn advies uit voordat de crisis werkelijkheid werd). Als de recessie in 2009 een feit wordt, zal men niet kunnen ontkomen aan het ontslaan van personeel, maar deze deskundigen verwachten dat de krapte op de arbeidsmarkt structureel zal worden en vinden dat zo veel mogelijk werkenden tot hun 65ste jaar moeten doorwerken. Het Researchcentrum voor Onderwijs en Arbeidsmarkt (ROA) gaat er - op basis van onderzoek - nog steeds van uit dat er de komende jaren genoeg werk te vinden zal zijn in de techniek, het onderwijs en de gezondheidszorg. Belangrijkste veroorzaker is de noodzakelijke vervanging van de vertrekkende ouderen in die sectoren. Met name het tekort aan vakkrachten zal groot blijven. Vooral voor hbo-studenten en universitair opgeleiden blijven de toekomstperspectieven in het algemeen florissant.

Het ministerie van SZW heeft zelfs per 1 januari 2009 een 'doorwerkbonus' geïntroduceerd, om 62-plussers te prikkelen langer te blijven werken. Ook degenen die na hun 65 ste levensjaar willen blijven doorwerken, kunnen gebruikmaken van deze nieuwe regeling. De minister zei in januari 2009 op de televisie nog dat we zorgvuldig moeten omgaan met de oudere werknemers: 'degenen die vertrokken zijn krijg je niet meer terug,' zei hij letterlijk.

Aan de andere kant staat hoogleraar Arbeidsverhoudingen Paul de Beer. In een artikel in NRC Handelsblad van 18 december van 2008 geeft hij als zijn mening dat afvloeiing van oudere werknemers geen probleem zal zijn. Op de korte termijn voorkomt het dat personeel gedwongen ontslagen moet worden. En op de lange termijn denkt hij dat vraag en aanbod op de arbeidsmarkt op elkaar reageren, en dat bedrijven dus versneld technologisch zullen vernieuwen of hun productie naar het buitenland zullen verplaatsen, indien ze geen personeel kunnen vinden. Ze passen hun vraag naar arbeid dus aan

* Peter Smulders is werkzaam bij TNO Arbeid en redacteur van het Tijdschrift voor Arbeidsvraagstukken. E-mail: Peter.Smulders@tno.nl. 
het aanbod aan. Daarom kunnen bedrijven het voor oudere werknemers dit jaar best aantrekkelijk maken om een of twee jaar eerder uit te treden, stelt De Beer.

De toekomst zal leren welke arbeidsmarktstrategie op termijn het beste zal uitpakken voor het Nederlandse bedrijfsleven. Alles hangt natuurlijk af van de ernst en de duur van de crisis. Hoe het jaar 2009 zal verlopen, is nog allerminst duidelijk. Een jaar geleden waren de verwachtingen voor het jaar 2008 bijvoorbeeld heel optimistisch. Wellicht vergissen de economische toekomstvoorspellers zich opnieuw en zal 2009 toch een licht herstel laten zien. In dat geval is de strategie van Donner het beste. Aan de andere kant wordt zelfs de zogenaamde Kondratieff-cyclus - de theorie van de lange economische golven - van stal gehaald en als we daarin terechtkomen zou het nog wel een decennium of langer kunnen duren voordat we uit het dal klimmen. Dan wordt het scenario van De Beer zeker werkelijkheid.

Voorlopig lijkt het het beste om het zekere voor het onzekere te nemen, en het adagium van Donner te volgen: zet de oudere werknemers niet te snel aan de kant, want je krijgt ze niet meer terug.

Het Tijdschrift voor Arbeidsvraagstukken heeft eerder - in nummer 2 van 2006 en in nummer 3 van 2007 - uitgebreid aandacht besteed aan de gevolgen van de vergrijzing voor het Nederlandse arbeidsbestel en hoe oudere werknemers te stimuleren langer door te werken.

Van Hoof en De Beer (2007) memoreerden in hun inleiding bij het TvA-themanummer over 'De vergrijzende arbeidsorganisatie' dat de arbeidsparticipatie van 55-plussers van 1996 tot 2007 opgelopen was van $26 \%$ tot $42 \%$. Als redenen hiervoor noemden ze:

1 de verhoging van de zogenaamde spilleeftijd in de regelingen voor vervroegde uittreding;

2 de omzetting van de VUT in prepensioen;

3 de verscherping van de toetredingscriteria voor de arbeidsongeschiktheidsuitkeringen;

4 de stijging van het gemiddelde opleidingsniveau van 55-plussers, die verbonden is met een hogere arbeidsdeelname;

5 de invloed van de emancipatie die vrouwen tot (door)werken aanzet.

Van Hoof en De Beer signaleerden een grote mate van werkgeversimmobilisme rond de arbeidsparticipatie van ouderen. De meeste werkgevers doen weinig moeite om hun eigen oudere werknemers langer aan de gang te houden, maar volstaan met een aantal 'ontzie'-maatregelen, die gebaseerd zijn op CAO-afspraken (zie voor meer details het artikel van Tros (2008) in dit tijdschrift). En, stelden Van Hoof en De Beer, bij het vervullen van vacatures gaan werkgevers geheel aan oudere werkzoekenden voorbij. Door deze weigerachtige houding van de werkgevers, zagen deze auteurs alleen het paardenmiddel van de verhoging van de pensioengerechtigde leeftijd door de overheid als logische volgende stap in de richting van verdere verhoging van de arbeidsparticipatie van ouderen.

In het eerste nummer van 2008 is door Jettinghoff en Smulders (2008) aandacht besteed aan de factoren die langer doorwerken remmen of bevorderen. Daarbij spelen het beperken van werkdruk en fysieke belasting, het stimuleren van ontwikkelingsmogelijkheden en gezondheid van de werknemer een hoofdrol. Mocht de arbeidsmarkt 
krap blijven, dan kunnen deze conclusies bruikbaar zijn voor het vormgeven van bedrijfsbeleid ten aanzien van het behoud van oudere werknemers. Omdat gezondheidsschade bij werknemers vaak al op jonge leeftijd een begin krijgt (denk aan rugklachten door zwaar tillen in de bouw, waardoor ouderen soms al op hun 50ste het werk moeten verlaten), dient dat beleid niet alleen op ouderen, maar zeker ook al op jongeren gericht te zijn.

Ondanks de economische crisis en de onzekerheid op de arbeidsmarkt gaat het in dit eerste nummer van 2009 opnieuw over de oudere werknemer. Dit thema komt in drie bijdragen aan de orde. Ze borduren ten dele voort op de problematiek die Van Hoof en De Beer in 2007 aanroerden. Allereerst belichten Otten en Siermann - in een nieuwe CBS-rubriek in TvA - de verschuivingen in het arbeidspotentieel van ouderen in de periode 1996-2007. Zij laten cijfermatig zien dat de arbeidsparticipatie van ouderen in die periode in de lift zat. En hun arbeidsdeelname zal, mede door stimulerend beleid, maar vooral door de aanhoudende instroom van jongere generaties met steeds meer werkende vrouwen, ook in de komende jaren verder toenemen, is hun conclusie. Daarnaast is er een artikel van Van Dalen, Henkens en Schippers, dat de visie belicht die werkgevers en werknemers hebben op de productiviteit van oudere werknemers. Bij werkgevers blijken 'harde' factoren als mentale en fysieke belastbaarheid van ouderen doorslaggevend voor het beeld dat zij hebben. Bij werknemers spelen 'zachte' factoren als betrouwbaarheid, betrokkenheid en sociale vaardigheden een grotere rol. Deze auteurs concluderen dat de uitdaging van de vergrijzing voor ondernemend Nederland vooral ligt in de noodzaak die 'zachte' kwaliteiten in voldoende mate rendabel te maken. De derde bijdrage over de arbeidsparticipatie van ouderen is van de hand van Kerkhofs, Fouarge en Ester. In dit artikel wordt nagegaan hoe gevoelig werknemers bij de keuze van hun pensioenleeftijd zijn voor financiële prikkels. De resultaten laten zien dat versobering inderdaad leidt tot latere uittreding.

Gezien de grote economische omwentelingen die zich thans voordoen, en de mogelijkheid dat bedrijven overgaan tot het laten vertrekken van oudere werknemers, zullen we ongetwijfeld op het thema vergrijzing en arbeidsparticipatie van ouderen terugkomen.

\section{Literatuur}

Beer, P. de (2008). Recessie komt als geroepen. NRC Handelsblad, 18 december 2008. Ook te vinden op www.mejudice.nl/node/122.

Hoof, J. van \& Beer, P. de (2007). Inleiding: Werkgeversimmobilisme. Tijdschrift voor Arbeidsvraagstukken, 23, 191-194.

Jettinghoff, K. \& Smulders, P.G.W. (2008). Wie kan en wil doorwerken tot 65-jarige leeftijd? Tijdschrift voor Arbeidsvraagstukken, 24, 88-100.

Tros. F. (2008). Flexicurity voor ouderen in Europese bedrijven. Tijdschrift voor Arbeidsvraagstukken, 24, 402-420. 